\title{
Effect of Superheated Steam Treatment on the Lipid Stability of Dried Whole Wheat Noodles during Storage
}

\author{
Wan-Ting Jia $\left(D\right.$, Zhen Yang, Xiao-Na Guo ${ }^{D}$ and Ke-Xue Zhu *(D) \\ State Key Laboratory of Food Science and Technology, School of Food Science and Technology, \\ Jiangnan University, 1800 Lihu Avenue, Wuxi 214122, China; 6180112021@stu.jiangnan.edu.cn (W.-T.J.); \\ zhen.yang@jiangnan.edu.cn (Z.Y.); xiaonaguo@jiangnan.edu.cn (X.-N.G.) \\ * Correspondence: kxzhu@jiangnan.edu.cn; Tel./Fax: +86-510-8532-9037
}

check for updates

Citation: Jia, W.-T.; Yang, Z.; Guo, X.-N.; Zhu, K.-X. Effect of Superheated Steam Treatment on the Lipid Stability of Dried Whole Wheat Noodles during Storage. Foods 2021, 10, 1348. https://doi.org/10.3390/ foods10061348

Academic Editor: Francesca Venturi

Received: 25 April 2021

Accepted: 9 June 2021

Published: 11 June 2021

Publisher's Note: MDPI stays neutral with regard to jurisdictional claims in published maps and institutional affiliations.

Copyright: (c) 2021 by the authors. Licensee MDPI, Basel, Switzerland. This article is an open access article distributed under the terms and conditions of the Creative Commons Attribution (CC BY) license (https:// creativecommons.org/licenses/by/ $4.0 /)$.

\begin{abstract}
Dried whole wheat noodles (DWWN) are a kind of nutritious convenience food with broad market prospects. However, due to the presence of high content of unsaturated fatty acids (UFAs) and lipid degrading enzymes, the shelf life and edible quality of DWWN are easily affected. This study explored the effect of superheated steam treatment (SST-155 ${ }^{\circ} \mathrm{C}-10 \mathrm{~s}, \mathrm{SST}-170{ }^{\circ} \mathrm{C}-10 \mathrm{~s}$, SST- $190^{\circ} \mathrm{C}-5 \mathrm{~s}$ ) on the lipid stability of DWWN. The lipase, lipoxygenase and peroxidase of the DWWN treated with superheated steam were completely passivated during storage. After 12 weeks of storage, the fatty acid value of DWWN increased by 35.1, 17.9, 15.9, $24.6 \mathrm{mg} \mathrm{NaOH} / 100 \mathrm{~g}$ in the groups of control, SST- $155{ }^{\circ} \mathrm{C}-10 \mathrm{~s}$, SST- $170{ }^{\circ} \mathrm{C}-10 \mathrm{~s}$, SST- $190{ }^{\circ} \mathrm{C}-5 \mathrm{~s}$, respectively; whereas the content of UFAs decreased by $13.5 \%, 6.8 \%, 5.4 \%$, and $2.7 \%$, respectively. The content of 2-pentylfuran in the SST- $155{ }^{\circ} \mathrm{C}-10 \mathrm{~s}, \mathrm{SST}-170{ }^{\circ} \mathrm{C}-10 \mathrm{~s}$, SST- $190{ }^{\circ} \mathrm{C}-5 \mathrm{~s}$ group was $0.7,0.6$, and 0.4 -fold than that of the control group, respectively. In addition, the total tocopherol and total volatile compounds of the SST- $190{ }^{\circ} \mathrm{C}-5 \mathrm{~s}$ group were 2.4 and 0.7 -fold than that of the control group, respectively. Therefore, SST should be a new technology that can improve the lipid stability of DWWN.
\end{abstract}

Keywords: dried whole wheat noodles; superheated steam treatment; lipid stability; enzyme activity; tocopherols; volatile compounds

\section{Introduction}

Intake of dietary fiber and phytochemicals can help reduce the risk of chronic diseases (such as cancer, diabetes, and cardiovascular disease) [1,2]. In recent years, whole-grain foods such as whole wheat and coarse cereals have attracted more attention because they are rich in dietary fiber, minerals and phytochemicals [3-5]. Whole wheat is rich in tocols (tocopherols and tocotrienols), whose content is about 27.6-79.7 $\mu \mathrm{g} / \mathrm{g}$ flour [6]. Tocols are the most important compounds with antioxidant activity in vegetable oils. It can not only inhibit the peroxidation of unsaturated fatty acids (UFAs) and other compounds [7], but also prevent neurological diseases, induce immune responses and lower cholesterol [8]. Noodles are one of the most popular staple foods in Asian countries, and their raw materials account for about $20-50 \%$ of the total wheat flour [4]. Dried noodles originated in China, with the characteristics of easy storage and convenient eating, and a high degree of industrialization. In addition, dried whole wheat noodles (DWWN) meet the needs of consumers who desire healthy and low-calorie foods $[4,9]$.

However, one of the main factors affecting the development of DWWN industry is the short shelf-life. The content of UFAs and the activity of lipid degrading enzymes in DWWN are higher than that of ordinary dried noodles due to the presence of bran and germ [2,10]. Lipid degrading enzymes can act on UFAs to produce a series of lipid hydrolysis and oxidation reactions, resulting in bad odors, which affects the nutritional quality and edible quality of DWWN [10,11]. Moreover, the rate of lipid hydrolysis and oxidation was significantly correlated with the activity of lipid degrading enzymes such as lipase, lipoxygenase (LOX) and peroxidase (POD) [2,10,11]. Lipase generally acts on 
the ester bonds of triglycerides and releases free fatty acids (FFAs) [11]. LOX catalyzes the enzymatic oxidation of UFAs to form hydroperoxides [12]. POD can decompose hydroperoxides into small molecular compounds, such as aldehydes, ketones, and organic acids [13].

At present, inactivating the lipase and LOX in whole wheat flour (WWF) is an effective way to extend the shelf life of DWWN. Some processing methods including hot air treatment, steam treatment, microwave and irradiation have been widely used to stabilize WWF and wheat bran $[2,13,14]$. However, these traditional treatment methods have some limitations, such as incomplete enzyme inactivation, promotion of auto-oxidation, impaired nutritional quality $[15,16]$. In recent years, superheated steam treatment (SST) has appeared as an emerging technology to inactivate enzymes and decontaminate microorganisms [17]. SST is the dry steam generated by adding sensible thermal energy to wet saturated steam, which makes the steam temperature higher than the corresponding boiling point or saturation point in a certain pressure [18]. If only its temperature is kept above the saturation point, it has the ability to absorb moisture and is suitable for processing dry food materials [17]. Superheated steam has a large heat transfer coefficient, high thermal efficiency, and high temperature, resulting in a short processing time and energy saving (steam can be recycled) $[2,19,20]$. Studies have shown that SST is an effective and feasible method of stabilization, which can effectively reduce the activities of lipase and LOX, while having little effect on phenols, flavonoids and antioxidant activity [2,15-17]. This is because superheated steam treatment can provide an oxygen free environment, which is conducive to inhibiting lipid oxidation [15]. Superheated steam has been used to inactivate enzymes and dry cereals such as wheat, brown rice and oats [21]. However, the effect of SST on the lipid stability of DWWN has not been reported yet.

The aim of the present study was to explore the effect of SST-processed WWF on the lipid stability of DWWN during storage. This study used SST-processed WWF to prepare DWWN, and determined its enzyme activity, fatty acid value, fatty acid composition, tocols content and volatile compounds during storage. The results of this study indicated that SST could significantly improve the lipid stability of DWWN during storage. Therefore, this study proposed a new method to improve the lipid stability of DWWN, which provided a theoretical basis for industrial production.

\section{Materials and Methods}

\subsection{Reagents and Raw Material}

Guaiacol and linoleic acid were purchased from Macklin Biochemical Co., Ltd. (Shanghai, China), and 4-nitrophenyl caprylate was purchased from Alfa Aesar Chemical Co., Ltd. (Shanghai, China). The $\alpha-, \beta-, \gamma-$, and $\delta$-tocopherol standards, and methyl nonadecylate were purchased from Sigma-Aldrich Co., Ltd. (St. Louis, MO, USA). Tocomin SupraBio (containing four tocopherols and four tocotrienols) was purchased from Healthy Origins Inc. (Perak, Malaysia). All other reagents, including isopropanol, heptane and 1,4-dioxane were purchased from Merck KGaA (Darmstadt, Germany). The reagents were of analytical grade, and the solvents of high-performance liquid chromatography (HPLC) grade were purchased from Sinopharm Chemical Reagent Co., Ltd. (Shanghai, China).

Raw materials including wheat bran and straight flour were provided by Yihai Kerry Grain, Oil and Food Industry Co., Ltd. (Dongguan, Guangdong Province, China). The wheat bran was ground by a low-temperature grinder (Mode SES-01, Wuxi Hepu Light Industrial Equipment Technology Co., Ltd., Jiangsu, China) and passed through an 80 mesh $(180 \mu \mathrm{m})$ standard experimental sieve. The wheat bran and straight flour were reconstituted into WWF according to the yield of real-time display and automatic calculation of the factory. The compositions of WWF were characterized according to the American Association of Cereal Chemists (AACC 2000) methods [22], including 12.85\% moisture (AACC method 44-01.01), 1.64\% fat (AACC method 30-25.01), 1.67\% ash (AACC method 08-12.01), 10.84\% protein (AACC method 39-11.01). The raw materials stored in the refrigerator at $-18{ }^{\circ} \mathrm{C}$ before analysis. 


\subsection{Superheated Steam Treatment of Whole Wheat Flour}

The WWF was treated using superheated steam powder sterilization equipment (Mode WS-FMD15, Jiangsu Wanchuang Sterilization Equipment Technology Co., Ltd., Jiangsu, China). The conditions and process of SST were as follows: when superheated steam reached set temperature, the $500 \mathrm{~g}$ of WWF was put into the feeding system. Then the steam stirring paddle drove the WWF to rotate at a speed of $1000 \mathrm{r} / \mathrm{s}$. Meanwhile, the superheated steam with the volume flow of $22 \mathrm{~m}^{3} / \mathrm{h}$ was fed into the processing chamber, so that the WWF suspended in the high-speed flowing superheated steam. The contact between WWF and superheated steam was uniform during SST. After SST, the WWF was separated from the steam through the separator equipped in the processing chamber. The separated WWF was cooled rapidly by a condenser. The parameters of SST were set at $155^{\circ} \mathrm{C}-10 \mathrm{~s}, 170{ }^{\circ} \mathrm{C}-10 \mathrm{~s}, 190^{\circ} \mathrm{C}-5 \mathrm{~s}$. After the SST processing, the treated WWF was stored in the refrigerator at $-18^{\circ} \mathrm{C}$ until use.

\subsection{Preparation and Storage Experiment of Dried Whole Wheat Noodles}

The dried noodles were prepared according to the method of Yu et al. [9] with some modifications. The DWWN formula consisted of $400 \mathrm{~g}$ of WWF, $108 \mathrm{~mL}$ of distilled water and $4 \mathrm{~g}$ of salt. Ingredients were mixed using a vacuum mixer (HWJZ-5, Nanjing, Jiangsu Province, China) for $7 \mathrm{~min}$ (vacuum degree was $-0.08 \mathrm{MPa}$ ). The mixed dough was put into a sealed bag and left to rest for $30 \mathrm{~min}$ at $25^{\circ} \mathrm{C}$ and $75 \%$ relative humidity (RH). Then, the dough was passed through a small noodles machine (JMTD-168/140, Beijing, China) to get $1 \mathrm{~mm}$ thick and wide wet noodles. Finally, DWWN was obtained by using a drying equipment for dried noodles (SYT-030, Beijing, China) to dry in stages for $230 \mathrm{~min}$. The drying process of dried noodles included five stages, and the temperature, $\mathrm{RH}$ and time of each stage were different: Stage I: $35^{\circ} \mathrm{C}, 80 \% \mathrm{RH}, 35 \mathrm{~min}$; Stage II: $40{ }^{\circ} \mathrm{C}, 70 \% \mathrm{RH}, 35 \mathrm{~min}$; Stage III: $45{ }^{\circ} \mathrm{C}, 60 \% \mathrm{RH}, 85 \mathrm{~min}$; Stage IV: $40{ }^{\circ} \mathrm{C}, 60 \% \mathrm{RH}, 35 \mathrm{~min}$; Stage V: $30{ }^{\circ} \mathrm{C}, 60 \% \mathrm{RH}$, $40 \mathrm{~min}$.

The DWWN (the length was about $20 \mathrm{~cm}$ ) was packed in vacuum bags and sealed using a heat-sealing machine (D2 300/5SA, Dongguan, Guangdong Province, China), and then stored at $40{ }^{\circ} \mathrm{C}$ and $75 \% \mathrm{RH}$ in an incubator for storage experiment. The thickness of the vacuum packaging bag was $0.2 \mathrm{~mm}$, which was made of polyethylene terephthalate and polyethylene composite processing. The samples were taken and analyzed in an interval of 3 weeks. In addition, a portion of DWWN was cut into $1 \mathrm{~cm}$ length and stored in dark-brown headspace bottles at the same condition to determine volatile compounds in order to avoid the loss of odor. The DWWN made from WWF without SST was used as a control group. The DWWN were crushed by high-speed universal crusher (FW100, Shanghai, China), and then passed through an 80 mesh $(180 \mu \mathrm{m})$ standard experimental sieve to obtain dried noodles flour.

\subsection{Determination of Lipase, Lipoxygenase and Peroxidase Activity}

\subsubsection{Determination of Lipase Activity}

The lipase activity of DWWN was determined referring to the method of Cai et al. [23] with some modifications. The $2 \mathrm{~g}$ of dried noodles flour was mixed with $10 \mathrm{~mL}$ of Tris-HCl $(\mathrm{pH} 8.0,50 \mathrm{mM})$ buffer using a vortex, then the mixture was placed in an ice bath at 4 ${ }^{\circ} \mathrm{C}$ for $30 \mathrm{~min}$ and shaken intermittently during the period. After that, the mixture was centrifuged with a centrifuge (H2050R, Xiangyi Laboratory Instrument Development Co., Ltd., Hunan, China) for $10 \mathrm{~min}\left(4^{\circ} \mathrm{C}, 10,275 \times g\right)$, the supernatant was filtered through a $0.45 \mu \mathrm{m}$ filter membrane to obtain the crude enzyme solution. To start the reaction, $1.78 \mathrm{~mL}$ of Tris- $\mathrm{HCl}$ buffer, $20 \mu \mathrm{L}$ of $10 \mathrm{mM}$ 4-nitrophenol caprylate substrate and $200 \mu \mathrm{L}$ of crude enzyme solution were added into the enzyme label plate in sequence. The absorbance change of the reaction solution was determined within $3 \mathrm{~min}$ at $37^{\circ} \mathrm{C}$ and $405 \mathrm{~nm}$ using a microplate reader (Bio Tek Epoch 2, Berten Instrument Co., Ltd., Burlington, VT, USA). Enzyme activity was expressed as the absorbance of the reaction system increases by 0.01 to $1 \mathrm{U}$ per minute, and finally the unit was converted to $\mathrm{U} / \mathrm{g} \cdot \mathrm{min}^{-1}$. 


\subsubsection{Determination of Lipoxygenase Activity}

The lipoxygenase activity of DWWN was determined referring to the research method of Cato et al. [24] with some modification. The $1 \mathrm{~g}$ of dried noodles flour was mixed with $10 \mathrm{~mL}$ of phosphate buffer solution ( $\mathrm{pH} 7.5,0.1 \mathrm{~mol} / \mathrm{L})$ using a vortex, then the mixture was extracted with ice bath for $30 \mathrm{~min}$. After that, the mixture was centrifuged with a centrifuge for $20 \min \left(4^{\circ} \mathrm{C}, 10,275 \times g\right)$, then the supernatant solution was filtered through a $0.45 \mu \mathrm{m}$ filter membrane to obtain the crude enzyme solution. The substrate solution was prepared by dissolving $99.93 \mathrm{mg}$ of linoleic acid standard into $10 \mathrm{~mL}$ of absolute ethanol in a nitrogen atmosphere. Then, $80 \mu \mathrm{L}$ of tween 20 was added to $7.1 \mathrm{~mL}$ of the prepared substrate solution. A rotary evaporator was used to remove the ethanol, and the residue was dissolved in $100 \mathrm{~mL}$ of $0.05 \mathrm{~mol} / \mathrm{L} \mathrm{Na}_{2} \mathrm{HPO}_{4}$. Then the $\mathrm{pH}$ was adjusted using $1 \mathrm{~mol} / \mathrm{L}$ $\mathrm{NaOH}$ to a final value of $\mathrm{pH}=9$. The concentrations of linoleic acid and tween-20 in the substrate solution were $2.53 \mathrm{mmol} / \mathrm{L}$ and $0.08 \%(w / v)$, respectively. To start the reaction, $2.89 \mathrm{~mL}$ acetate buffer $(0.05 \mathrm{~mol} / \mathrm{L}, \mathrm{pH}=5.5), 90 \mu \mathrm{L}$ of substrate solution and $20 \mu \mathrm{L}$ enzyme solution was added successively, and the absorbance change of the reaction system was determined within $3 \mathrm{~min}$ at $234 \mathrm{~nm}$ using a spectrophotometer (TU-1810, Puxi General Instrument Co., Ltd., Beijing, China). Enzyme activity was expressed as the absorbance of the reaction system increases by 0.01 to $1 \mathrm{U}$ per minute, and finally the unit was converted to $\mathrm{U} / \mathrm{g} \cdot \mathrm{min}^{-1}$.

\subsubsection{Determination of Peroxidase Activity}

The peroxidase activity of DWWN was determined referring to the research method of Sessa et al. [25] and Jiang et al. [26] with slight modifications. The $2 \mathrm{~g}$ of dried noodles flour was mixed with $10 \mathrm{~mL}$ of distilled water, then the mixture was placed at room temperature for $30 \mathrm{~min}$ and shaken intermittently during the period. Then, the mixture was centrifuged for $10 \mathrm{~min}\left(25^{\circ} \mathrm{C}, 10,275 \times g\right)$, and the supernatant solution was the enzyme extract. The mixture of $\mathrm{H}_{2} \mathrm{O}_{2}$ solution $\left(30 \% \mathrm{H}_{2} \mathrm{O}_{2}\right.$ : water $\left.=1: 29, v / v\right)$ and guaiacol solution $(1 \%$ guaiacol: $96 \%$ ethanol $=1: 99, v / v)$ were premixed at the ratio of $1: 1$. After that, the $600 \mu \mathrm{L}$ of the mixture and $1.2 \mathrm{~mL}$ of the enzyme extract were added to the enzyme label plate to start the reaction. The absorbance change of the reaction system was determined at $470 \mathrm{~nm}$ within $3 \mathrm{~min}$ using a microplate reader. Enzyme activity was expressed as the absorbance of the reaction system increases by 0.01 to $1 \mathrm{U}$ per minute, and finally the unit was converted to $\mathrm{U} / \mathrm{g} \cdot \mathrm{min}^{-1}$.

\subsection{Extraction of Lipids from Dried Whole Wheat Noodles}

The extraction of lipids in DWWN was carried out according to the method of Yao et al. [27] using an accelerated solvent extraction (ASE) instrument (DIONEX ASE350, Thermo Fisher Scientific Co., Ltd., Waltham, MA, USA). The $1 \mathrm{~g}$ of dried noodles flour was mixed with the same amount of quartz sand in an $11 \mathrm{~mL}$ of extraction cell, then filled the cells with quartz sand. Lipid extraction was carried out with ASE under the condition of 1000 psi pressure and $100^{\circ} \mathrm{C}$ temperature with a preheating time of $5 \mathrm{~min}$, and 2 static extraction cycles of $10 \mathrm{~min}$. The extraction solvent was acetone. Then, the extract was transferred to a round-bottomed flask, and evaporated under reduced pressure using a rotary evaporator at $40^{\circ} \mathrm{C}$. Finally, the dried lipids were dissolved in $10 \mathrm{~mL}$ of heptane for further analysis.

\subsection{Determination of Fatty Acid Composition}

The fatty acid composition of DWWN was determined referring to the method of Shin et al. [28]. The content of lipids and fatty acid composition in DWWN were determined by a gas chromatograph (GC-2010PLUS, Shimadzu Co., Ltd., Tokyo, Japan) coupled with a flame ionization detector (GC-FID). An external standard method was used to quantify the fatty acid methyl ester (the external standard was methyl nonadecylate). The content of lipids was calculated by the sum of fatty acid methyl ester. The $2 \mathrm{~mL}$ of the lipid solution prepared in Section 2.5 was transferred into $10 \mathrm{~mL}$ clean glass tubes and dried 
with nitrogen. Then $2 \mathrm{~mL}$ of $2 \% \mathrm{NaOH}-\mathrm{CH}_{3} \mathrm{OH}$ solution was added to dissolve the oil droplets, and the solution was heated at $65{ }^{\circ} \mathrm{C}$ for $30 \mathrm{~min}$ until the oil droplets disappeared. After cooling to room temperature, $2 \mathrm{~mL}$ of $14 \% \mathrm{BF}_{3}-\mathrm{CH}_{3} \mathrm{OH}$ solution was added and the above heating process was repeated. After cooling, $2 \mathrm{~mL}$ of heptane was added and the lipids were extracted by shaking for $5 \mathrm{~min}$. Then, $2 \mathrm{~mL}$ saturated $\mathrm{NaCl}$ solution was added and allowed to stand for $2 \mathrm{~h}$. After that, the upper organic phase was transferred into a test tube containing $0.5 \mathrm{~g}$ of anhydrous sodium sulfate and left for $30 \mathrm{~min}$. Finally, the solution was collected to filter through a $0.22 \mu \mathrm{m}$ filter membrane for GC analysis.

The GC conditions were set as follows: the chromatographic column was DB-WAX capillary column $(30 \mathrm{~m} \times 0.25 \mathrm{~mm} \times 0.25 \mu \mathrm{m})$; the temperature of detector and injector was $250{ }^{\circ} \mathrm{C}$, the carrier gas was high-purity nitrogen with a flow rate of $3 \mathrm{~mL} / \mathrm{min}$; the temperature rising program was as follows: the temperature was from $150{ }^{\circ} \mathrm{C}$ to $190{ }^{\circ} \mathrm{C}$ at the rate of $5{ }^{\circ} \mathrm{C} / \mathrm{min}$ and maintained for $2 \mathrm{~min}$, and then to $240{ }^{\circ} \mathrm{C}$ at the rate of $5^{\circ} \mathrm{C} / \mathrm{min}$ and maintained for $10 \mathrm{~min}$.

\subsection{Determination of Tocopherols and Tocotrienols Content}

The tocopherols and tocotrienols content of DWWN was determined referring to the method of Lampi et al. [6] with some modifications. The $\alpha-, \beta-, \gamma-$ and $\delta$-tocopherol standards were dissolved and preserved in heptane, the content of tocopherols in the samples were quantified by making calibration curves with the $\alpha-, \beta-, \gamma$ - and $\delta$ - tocopherol standards in the range of $2-150 \mathrm{ng}$ /injection. The tocotrienols in samples were identified by the commercially purchased Tocomin SupraBio product containing tocopherols and tocotrienols. Each of the tocotrienol was quantified with its corresponding calibration curve of tocopherol standard. The concentration and purity of the standard storage solution were checked with spectrophotometer in an interval of 4 weeks.

The content of tocopherols and tocotrienols in DWWN was determined by normal phase high-performance liquid chromatograph (Waters1525, Waters Co., Ltd., Milford, MA, USA) coupled with a fluorescence detector (NP-HPLC-FLD). The lipid solution prepared in Section 2.5 was pipetted through a $0.22 \mu \mathrm{m}$ filter membrane into a liquid phase bottle for analysis. The GC conditions were set as follows: the chromatographic column was Inertsil silica column $(30 \mathrm{~cm} \times 3.9 \mathrm{~mm}, 5 \mu \mathrm{m}$; Varian Inc.; Palo Alto, CA, USA), the mobile phase was heptane:1,4-dioxane $=97: 3$, the flow rate of the mobile phase was $1 \mathrm{~mL} / \mathrm{min}$ with isocratic elution at a column temperature of $30{ }^{\circ} \mathrm{C}$. The excitation wavelength $\left(\lambda_{\text {ex }}\right)$ of the FLD was $292 \mathrm{~nm}$, and the emission wavelength $\left(\lambda_{\mathrm{em}}\right)$ was $325 \mathrm{~nm}$.

\subsection{Characterization of Volatile Compounds}

The volatile compounds of DWWN were determined referring to the method of Paradiso et al. [29] with some modifications. Volatile compounds were determined by headspace solid-phase microextraction gas chromatograph coupled with mass spectrometer (HS-SPME-GC-MS) (TSQ Quantum XLS, Thermo Fisher Scientific Co., Ltd., Waltham, MA, USA). The extraction head was inserted into the $20 \mathrm{~mL}$ of headspace bottle containing $2 \mathrm{~g}$ of DWWN, and extracted for $30 \mathrm{~min}$ at $60{ }^{\circ} \mathrm{C}$. After extraction, the sample was injected quickly and the resolution time was $5 \mathrm{~min}$. The GC-MS spectrum was matched and searched with Wiley 7N (Wiley Registry ${ }^{\mathrm{TM}}$ of Mass Spectral Data, 7th Edition, Scientific Instrument Services Inc., Ringoes, NJ, USA) database.

The GC conditions were set as follows: the flow rate of helium was $0.8 \mathrm{~mL} / \mathrm{min}$ and splitless injection, and the chromatographic column was capillary column DB-WAX $(30 \mathrm{~m} \times 0.25 \mathrm{~mm} \times 0.25 \mu \mathrm{m})$. The heating program was as follows: the initial temperature was kept at $40{ }^{\circ} \mathrm{C}$ for $4 \mathrm{~min}$, the temperature was increased to $70^{\circ} \mathrm{C}$ at the rate of $5^{\circ} \mathrm{C} / \mathrm{min}$, then the temperature was increased to $250^{\circ} \mathrm{C}$ at $10^{\circ} \mathrm{C} / \mathrm{min}$ and maintained for $8 \mathrm{~min}$. The MS conditions are as follows: the ionization energy was $70 \mathrm{eV}$, ion source temperature was $200{ }^{\circ} \mathrm{C}$ and ions were scanned from 33 to $450 \mathrm{amu}$. The analysis was calibrated using an alkane solution (n-butane to n-hexadecane). Total ion counts were used for quantifying 
the amounts of compounds, and the content of volatile compounds in the sample was expressed by peak area and relative content.

\subsection{Determination of Fatty Acid Value}

Fatty acid value of DWWN was determined by a titration of Zhao et al. [30] with slight modifications. Firstly, $5.0 \mathrm{~g}$ of dried noodles flour was mixed with $30 \mathrm{~mL}$ of $95 \%$ ethanol and extracted by shaking for $1 \mathrm{~h}$. After centrifugation for $10 \mathrm{~min}\left(25^{\circ} \mathrm{C}, 10275 \mathrm{~g}\right)$, the supernatant was collected and $20 \mathrm{~mL}$ of which was titrated with $0.05 \mathrm{~mol} / \mathrm{L} \mathrm{NaOH}-$ ethanol solution. The end point of titration was pink appeared and lasted for $30 \mathrm{~s}$ with phenolphthalein $(1 \%, w / v)$ as an indicator. The fatty acid value $(\mathrm{mg} \mathrm{NaOH} / 100 \mathrm{~g})$ of DWWN was calculated according to the Equation (1).

$$
\text { Fatty acid value }=600000 \times\left(V_{1}-V_{0}\right) \times c / m \times(100-w)
$$

where $V_{1}=$ volume of sample titration $(\mathrm{mL}), V_{0}=$ volume of blank titration $(\mathrm{mL})$, $c=$ normality of titrant $(\mathrm{mol} / \mathrm{L}), m=$ weight of sample $(\mathrm{g})$, and $w=$ moisture of sample $(\%)$.

\subsection{Statistical Analysis}

Analysis of one-way analysis of variance (ANOVA) with Tukey's test at a 95\% confidence level using SPSS version 22 (IBM SPSS statistics, International Business Machines Co., Ltd., Armonk, NY, USA). The influencing factors were SST-processed parameters and storage time. All results were expressed as mean \pm standard deviation (SD) of the least three replicates. The charts were drawn using origin 2018 (version pro9.1, Originlab Co., Ltd., Northampton, MA, USA).

\section{Results and Discussion}

\subsection{Changes of Enzyme Activity in Dried Whole Wheat Noodles during Storage}

According to the study of Guo et al. [2], when the temperature of SST was $155 / 170{ }^{\circ} \mathrm{C}$ and the treatment time was more than $10 \mathrm{~s}$, or when the treatment temperature was $190^{\circ} \mathrm{C}$ and the treatment time was more than $5 \mathrm{~s}$, the activities of lipase and LOX in WWF could not be detected. Therefore, three parameters of SST- $155{ }^{\circ} \mathrm{C}-10 \mathrm{~s}$, SST- $170{ }^{\circ} \mathrm{C}-10 \mathrm{~s}$, and SST- $190{ }^{\circ} \mathrm{C}-5 \mathrm{~s}$ were used to process WWF in this study.

As shown in Tables 1-3, the activities of lipase and POD were not detected in DWWN made from SST-processed WWF. In addition, compared with the control DWWN, the LOX activity was reduced by $67.6 \%, 69.3 \%, 71.3 \%$ in the SST $-155{ }^{\circ} \mathrm{C}-10 \mathrm{~s}$, SST- $-170{ }^{\circ} \mathrm{C}-10 \mathrm{~s}$, and SST- $190{ }^{\circ} \mathrm{C}-5 \mathrm{~s}$ group, respectively. In previous studies, the effectiveness of SST to inactivate enzymes was also reported. Hu et al. [15] found that the POD of wheat bran was completely inactivated after SST at $170^{\circ} \mathrm{C}$ for $7 \mathrm{~min}$. Wu et al. [31] found that the POD was completely inactivated after the lightly milled rice was processed by SST at $110 / 120^{\circ} \mathrm{C}$ for $3.5 / 2.5 \mathrm{~min}$. The activity of POD was used as an indicator of the heat treatment effect [31,32]. On the one hand, the inactivation of enzymes by SST may be due to the high temperature treatment destroyed the structure of the enzymes, leading to enzyme denaturation, which made lipase and LOX "inactivated" or "passivated" [33]. On the other hand, it may be because the high temperature treatment destroyed the water environment of enzyme-catalyzed reactions [34]. 
Table 1. Effect of superheated steam treatment on lipase activity of dried whole wheat noodles during storage.

\begin{tabular}{ccccc}
\hline \multirow{2}{*}{$\begin{array}{c}\text { Storage Time } \\
\text { (Weeks) }\end{array}$} & Control & SST-155 ${ }^{\circ}$ C-10 s & SST-170 ${ }^{\circ}$ C-10 s & SST-190 ${ }^{\circ}$ C-5 s \\
\cline { 2 - 5 } & $46.60 \pm 2.88^{\mathrm{a}, *}$ & - & - & - \\
\hline 0 & $34.11 \pm 2.88^{\mathrm{b}}$ & - & - & - \\
3 & $28.70 \pm 1.29^{\mathrm{b}, \mathrm{c}}$ & - & - & - \\
6 & $24.40 \pm 0.96^{\mathrm{c}, \mathrm{d}}$ & - & - & - \\
9 & $21.21 \pm 1.76^{\mathrm{d}}$ & - & - & - \\
12 & & - & -1 & - \\
\hline
\end{tabular}

* The superscript lowercase letters indicate the significant difference of the same sample in different storage time at $p<0.05$. SST: superheated steam treatment, -: the absorbance of the reaction system did not change within $3 \mathrm{~min}$.

Table 2. Effect of superheated steam treatment on lipoxygenase activity of dried whole wheat noodles during storage.

\begin{tabular}{ccccc}
\hline \multirow{2}{*}{$\begin{array}{c}\text { Storage Time } \\
\text { (Weeks) }\end{array}$} & Control & SST-155 ${ }^{\circ}$ C-10 s & SST-170 ${ }^{\circ}$ C-10 s & SST-190 ${ }^{\circ}$ C-5 s \\
\cline { 2 - 5 } & $574.43 \pm 35.32^{\mathrm{a}, *}$ & $186.18 \pm 20.76$ & $176.17 \pm 20.76$ & $164.84 \pm 7.06$ \\
0 & $217.87 \pm 2.83^{\mathrm{b}}$ & - & - & - \\
3 & $51.97 \pm 3.46^{\mathrm{c}}$ & - & - & - \\
6 & $49.83 \pm 0.00^{\mathrm{c}}$ & - & - & - \\
9 & $39.98 \pm 0.00^{\mathrm{c}}$ & - & - & - \\
\hline 12 &
\end{tabular}

* The superscript lowercase letters indicate the significant difference of the same sample in different storage time at $p<0.05$. SST: superheated steam treatment, $-:$ the absorbance of the reaction system did not change within $3 \mathrm{~min}$.

Table 3. Effect of superheated steam treatment on peroxidase activity of dried whole wheat noodles during storage.

\begin{tabular}{ccccc}
\hline \multirow{2}{*}{$\begin{array}{c}\text { Storage Time } \\
\text { (Weeks) }\end{array}$} & Control & SST-155 ${ }^{\circ}$ C-10 s & SST-170 ${ }^{\circ}$ C-10 s & SST-190 ${ }^{\circ}$ C-5 s \\
\cline { 2 - 5 } & $1412.36 \pm 66.66^{\mathrm{a}, *}$ & - & - & - \\
3 & $668.21 \pm 43.90^{\mathrm{b}}$ & - & - & - \\
6 & $579.85 \pm 61.01^{\mathrm{b}, \mathrm{c}}$ & - & - & - \\
9 & $514.56 \pm 18.61^{\mathrm{c}}$ & - & - & - \\
12 & $583.79 \pm 29.07^{\mathrm{b}, \mathrm{c}}$ & - & - & - \\
\hline
\end{tabular}

${ }^{*}$ The superscript lowercase letters indicate the significant difference of the same sample in different storage time at $p<0.05$. SST: superheated steam treatment, $-:$ the absorbance of the reaction system did not change within $3 \mathrm{~min}$.

During storage, the activities of lipase, LOX, and POD were not detected in all the SST groups. The initial activities of these enzymes were high in the control group, whereas they decreased significantly during storage $(p<0.05)$, i.e., by $54.5 \%$ (Table 1$)$ of lipase activity, by $93 \%$ of LOX activity (Table 2 ) and by $58.7 \%$ of POD activity (Table 3 ) after 12 weeks of storage. This may be due to the fact that lipase hydrolysis of lipids resulted in the accumulation of FFAs, which in turn inhibited lipase activity, and the storage temperature $\left(40{ }^{\circ} \mathrm{C}\right)$ deviated from the optimal temperature of lipase [35,36]. It may also be due to the significant decrease $(p<0.05)$ in moisture content during storage (Figure 1$)$, because moisture can change the fluidity of the substrate and the reactant or the active conformation of the enzyme [37]. The decrease in moisture content of all sample groups during storage may be caused by storage temperature $\left(40^{\circ} \mathrm{C}\right)$; on the other hand, it may be because the vacuum bags did not completely block the moisture exchange between dried noodles and the outside world [38]. Xu et al. [39] found that lipase could hydrolyze lipids to generate FFAs, and lipase activity was significantly related to water activity. In conclusion, the SST significantly inhibited the activities of lipase, LOX and POD of DWWN during storage. 


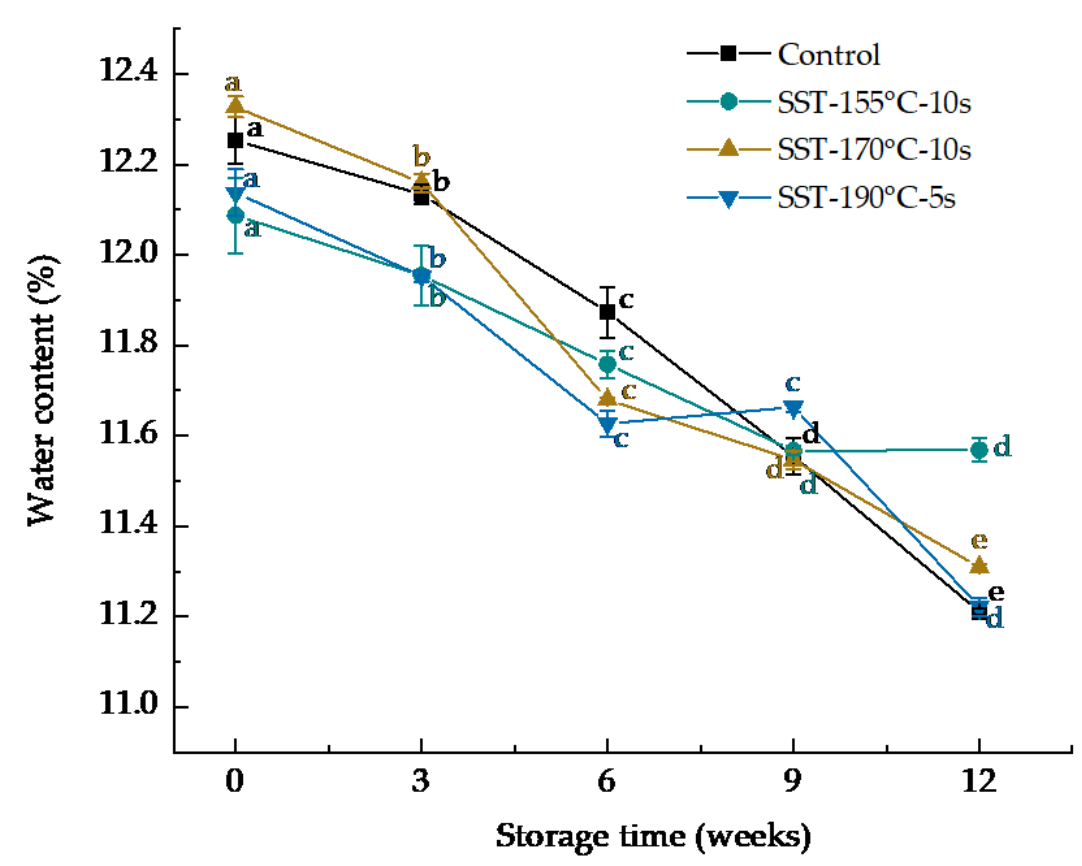

Figure 1. Effect of superheated steam treatment on moisture content of dried whole wheat noodles during storage. The lowercase letters indicate the significant difference of the same sample in different storage time at $p<0.05$. SST: superheated steam treatment.

\subsection{Changes of Fatty Acid Value in Dried Whole Wheat Noodles Storage}

The fatty acid value of DWWN in the control group was $52.9 \mathrm{mg} \mathrm{NaOH} / 100 \mathrm{~g}$ (Figure 2). The fatty acid value of DWWN made from SST-processed WWF was slightly decreased. For example, the values in SST- $155{ }^{\circ} \mathrm{C}-10 \mathrm{~s}$, SST- $170{ }^{\circ} \mathrm{C}-10 \mathrm{~s}$, SST- $190{ }^{\circ} \mathrm{C}-5 \mathrm{~s}$ group decreased by $11.9 \%, 24.1 \%$, and $18.5 \%$, respectively (Figure 2). The hydrolysis of triacylglycerol by lipase led to the accumulation of FFAs. The UFAs in FFAs can undergo enzymatic oxidation or auto-oxidation to form hydroperoxides. Therefore, FFAs were not only the products of enzymatic hydrolysis, but also the reaction substrates of enzymatic oxidation/auto-oxidation $[40,41]$. The fatty acid value of DWWN decreased after SST, which may be due to the high temperature during the heat treatment that promoted the oxidation of UFAs in FFAs, or the inactivation of lipase by SST that inhibited the hydrolysis of lipids in the process of dried noodles [42].

As shown in Figure 2, the fatty acid value of the control group increased significantly during storage $(p<0.05)$, while the values in SST groups increased slowly. After 12 weeks of storage, the control group, SST- $155^{\circ} \mathrm{C}-10 \mathrm{~s}$, SST- $170{ }^{\circ} \mathrm{C}-10 \mathrm{~s}$, SST- $190{ }^{\circ} \mathrm{C}-5$ s group increased by $35.1,17.9,15.9,24.6 \mathrm{mg} \mathrm{NaOH} / 100 \mathrm{~g}$, respectively. The accumulation rate of FFAs was closely correlated with lipase activity [42]. In the SST groups, the lipase of DWWN was passivated but the fatty acid value still increased. This may be because the residual lipase activity unable to be detected due to the limitation of the lipase determination method, or it may be because the lipid is under the action of thermodynamics hydrolyzed to produce FFAs (the storage temperature of DWWN was $40^{\circ} \mathrm{C}$ ) [43]. To conclude, the result showed that the SST can effectively inhibit the growth of fatty acid value during the production process and storage period of DWWN. 


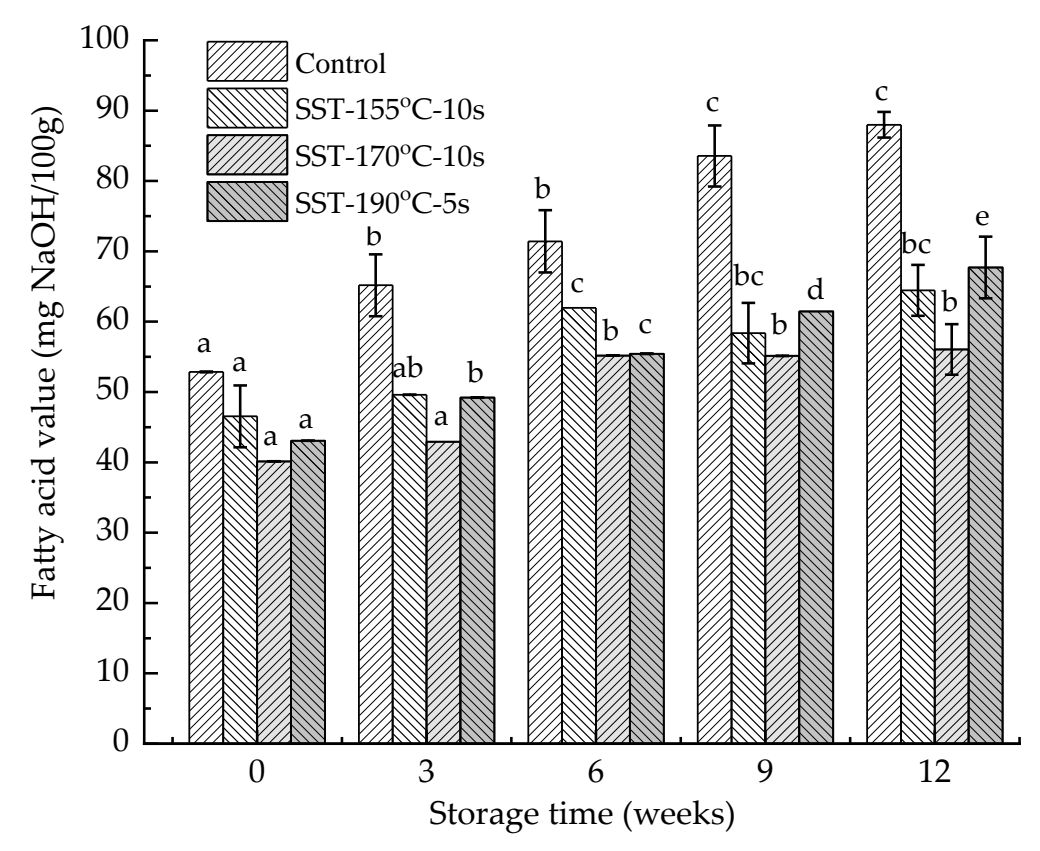

Figure 2. Effect of superheated steam treatment on fatty acid value of dried whole wheat noodles during storage. The lowercase letters in the column chart indicate the significant difference of the same sample in different storage time at $p<0.05$. SST: superheated steam treatment.

\subsection{Changes of Fatty Acid Composition in Dried Whole Wheat Noodles during Storage}

Changes of the fatty acid composition in the control group and the SST groups were shown in Table 4. The lipid content of control DWWN was $12.7 \mathrm{mg} / \mathrm{g}$. The fatty acids detected by GC-FID mainly included saturated fatty acids (SFAs, including palmitic acid, stearic acid) and UFAs (oleic acid, linoleic acid and linolenic acid), of which UFAs accounted for up to $77.3 \%$. Linoleic acid $(46.4 \%)$ had the highest content among UFAs in DWWN, followed by oleic acid $(20.6 \%)$ and linolenic acid $(10.3 \%)$. The results were consistent with Obadi et al. [44] and Mufari et al. [7]. As shown in Table 4, the content of UFAs in DWWN made from SST-processed WWF was significantly higher than that of control DWWN $(p<0.05)$, and there was no significant difference for SFAs $(p>0.05)$. At the initial stage of storage, the content of UFAs in the SST groups was 1.2-fold than that of the control group. This indicated that SST can significantly prevent the degradation of lipids during production of DWWN, whereas did not change its fatty acid composition.

The content of UFAs in all sample groups decreased during storage, among which the content of UFAs in the control group decreased significantly $(p<0.05)$, and there was no significant change in the SST- $190^{\circ} \mathrm{C}-5 \mathrm{~s}$ group $(p>0.05)$. After 12 weeks of storage, the content of UFAs in the control group, the SST- $155^{\circ} \mathrm{C}-10 \mathrm{~s}$, SST- $170{ }^{\circ} \mathrm{C}-10 \mathrm{~s}$, SST- $190{ }^{\circ} \mathrm{C}-5 \mathrm{~s}$ group decreased by $13.5 \%, 6.8 \%, 5.4 \%, 2.7 \%$, respectively. Linoleic acid decreased the most in all sample groups. This was because linoleic acid accounted for the highest proportion of UFAs, and more prone to oxidation than mono-unsaturated fatty acids such as oleic acid [45]. Among the three SST groups, the SST- $190^{\circ} \mathrm{C}-5 \mathrm{~s}$ group had the least degradation of UFAs after storage for 12 weeks, but the increase in fatty acid value was the largest (Figure 2). This may be because although the enzymatic oxidation pathways of all SST groups were blocked due to LOX inactivation, the auto-oxidation pathway rate in the SST- $190{ }^{\circ} \mathrm{C}-5 \mathrm{~s}$ group was lower than other SST groups due to the shorter treatment time $(5 \mathrm{~s})$, resulting in the accumulation of FFAs $[6,26,46]$. As a result, SST can effectively inhibit the degradation of UFAs during the production process and storage of DWWN, and the SST- $190^{\circ} \mathrm{C}-5 \mathrm{~s}$ group had the best inhibitory effect. 
Table 4. Effect of superheated steam treatment on fatty acid composition of dried whole wheat noodles during storage (mg/g flour, mean \pm standard deviation, $n=3$ ).

\begin{tabular}{|c|c|c|c|c|c|c|c|c|}
\hline \multirow{2}{*}{$\begin{array}{l}\text { Sample/Storage } \\
\text { Time (Weeks) }\end{array}$} & \multicolumn{8}{|c|}{ Fatty Acid Composition (mg/g) } \\
\hline & $\begin{array}{l}\text { Palmitic Acid } \\
\text { (C16:0) }\end{array}$ & $\begin{array}{l}\text { Stearic Acid } \\
\text { (C18:0) }\end{array}$ & Oleic Acid (C18:1) & $\begin{array}{l}\text { Linoleic Acid } \\
\text { (C18:2) }\end{array}$ & $\begin{array}{c}\text { Linolenic Acid } \\
\text { (C18:3) }\end{array}$ & Total SFAs & Total UFAs & Total FFAs \\
\hline \multicolumn{9}{|l|}{ Control } \\
\hline 0 & $2.24 \pm 0.01^{\mathrm{A}, \mathrm{a}, *}$ & $0.65 \pm 0.00^{\mathrm{A}, \mathrm{a}}$ & $2.62 \pm 0.00^{\mathrm{B}, \mathrm{a}}$ & $5.90 \pm 0.01^{\mathrm{C}, \mathrm{a}}$ & $1.31 \pm 0.00^{\mathrm{B}, \mathrm{a}}$ & $2.89 \pm 0.01^{\mathrm{A}, \mathrm{a}}$ & $9.83 \pm 0.02^{\mathrm{B}, \mathrm{a}}$ & $12.72 \pm 0.03^{\mathrm{B}, \mathrm{a}}$ \\
\hline 3 & $2.17 \pm 0.05^{\mathrm{B}, \mathrm{b}, \mathrm{c}}$ & $0.63 \pm 0.00^{\mathrm{B}, \mathrm{b}}$ & $2.60 \pm 0.05^{\mathrm{B}, \mathrm{a}}$ & $5.72 \pm 0.05^{\mathrm{C}, \mathrm{b}}$ & $1.31 \pm 0.01^{\mathrm{B}, \mathrm{a}}$ & $2.80 \pm 0.05^{\mathrm{B}, \mathrm{b}}$ & $9.63 \pm 0.04^{C, b}$ & $12.43 \pm 0.03^{C, b}$ \\
\hline 6 & $2.21 \pm 0.03^{\mathrm{A}, \mathrm{a}, \mathrm{b}}$ & $0.64 \pm 0.01^{\mathrm{A}, \mathrm{b}}$ & $2.58 \pm 0.10^{\mathrm{A}, \mathrm{a}}$ & $5.14 \pm 0.03^{\mathrm{B}, \mathrm{c}}$ & $1.31 \pm 0.02^{\mathrm{B}, \mathrm{a}}$ & $2.84 \pm 0.03 \mathrm{~A}, \mathrm{a}, \mathrm{b}$ & $9.04 \pm 0.09^{B, c}$ & $11.88 \pm 0.12^{\mathrm{B}, \mathrm{c}}$ \\
\hline 9 & $2.15 \pm 0.02^{\mathrm{D}, \mathrm{b}, \mathrm{c}}$ & $0.53 \pm 0.00^{\mathrm{B}, \mathrm{c}}$ & $2.45 \pm 0.01^{\mathrm{D}, \mathrm{b}}$ & $5.13 \pm 0.05^{\mathrm{D}, \mathrm{c}}$ & $1.09 \pm 0.00^{\mathrm{C}, \mathrm{b}}$ & $2.68 \pm 0.02^{\mathrm{D}, \mathrm{c}}$ & $8.67 \pm 0.06^{\mathrm{D}, \mathrm{d}}$ & $11.34 \pm 0.09^{\mathrm{D}, \mathrm{d}}$ \\
\hline \multicolumn{9}{|l|}{ SST- $155^{\circ} \mathrm{C}-10 \mathrm{~s}$} \\
\hline 0 & $2.27 \pm 0.02 \mathrm{~A}, \mathrm{a}$ & $0.65 \pm 0.00^{\mathrm{A}, \mathrm{a}}$ & $2.77 \pm 0.01 \mathrm{~A}, \mathrm{a}$ & $7.76 \pm 0.06^{\mathrm{A}, \mathrm{B}, \mathrm{a}}$ & $1.42 \pm 0.01^{\mathrm{A}, \mathrm{a}}$ & $2.92 \pm 0.02 \mathrm{~A}, \mathrm{a}$ & $11.95 \pm 0.07 \mathrm{~A}, \mathrm{a}$ & $14.87 \pm 0.10^{\mathrm{A}, \mathrm{a}}$ \\
\hline 3 & $2.23 \pm 0.05^{\mathrm{B}, \mathrm{a}}$ & $0.64 \pm 0.00^{\mathrm{B}, \mathrm{b}}$ & $2.69 \pm 0.06^{\mathrm{A}, \mathrm{B}, \mathrm{b}}$ & $7.43 \pm 0.22^{\mathrm{A}, \mathrm{B}, \mathrm{a}, \mathrm{b}}$ & $1.39 \pm 0.01 \mathrm{~A}, \mathrm{~b}$ & $2.87 \pm 0.06^{\mathrm{B}, \mathrm{a}}$ & $11.51 \pm 0.28^{\mathrm{A}, \mathrm{B}, \mathrm{b}}$ & $14.38 \pm 0.34^{\mathrm{B}, \mathrm{a}, \mathrm{b}}$ \\
\hline 6 & $2.25 \pm 0.09 \mathrm{~A}, \mathrm{a}$ & $0.64 \pm 0.01^{\mathrm{A}, \mathrm{a}, \mathrm{b}}$ & $2.68 \pm 0.07^{\mathrm{A}, \mathrm{b}, \mathrm{c}}$ & $7.13 \pm 0.36^{\mathrm{A}, \mathrm{B}, \mathrm{b}}$ & $1.37 \pm 0.02 \mathrm{~A}, \mathrm{~B}, \mathrm{~b}$ & $2.89 \pm 0.10^{\mathrm{A}, \mathrm{a}}$ & $11.18 \pm 0.45^{\mathrm{A}, \mathrm{B}, \mathrm{b}}$ & $14.07 \pm 0.55^{\mathrm{A}, \mathrm{B}, \mathrm{b}}$ \\
\hline 9 & $2.20 \pm 0.03^{C, a}$ & $0.53 \pm 0.00^{\mathrm{B}, \mathrm{c}}$ & $2.60 \pm 0.05^{\mathrm{C}, \mathrm{c}, \mathrm{d}}$ & $7.40 \pm 0.13^{\mathrm{C}, \mathrm{b}}$ & $1.16 \pm 0.01^{\mathrm{B}, \mathrm{c}}$ & $2.73 \pm 0.04^{C, b}$ & $11.16 \pm 0.17^{\mathrm{C}, \mathrm{b}}$ & $13.89 \pm 0.21^{C, b}$ \\
\hline 12 & $2.22 \pm 0.00^{\mathrm{B}, \mathrm{a}}$ & $0.53 \pm 0.00^{\mathrm{B}, \mathrm{c}}$ & $2.59 \pm 0.00^{\mathrm{B}, \mathrm{d}}$ & $7.39 \pm 0.04^{\mathrm{B}, \mathrm{b}}$ & $1.16 \pm 0.00^{\mathrm{B}, \mathrm{c}}$ & $2.74 \pm 0.00^{\mathrm{B}, \mathrm{b}}$ & $11.14 \pm 0.04^{\mathrm{B}, \mathrm{b}}$ & $13.89 \pm 0.04^{\mathrm{B}, \mathrm{b}}$ \\
\hline \multicolumn{9}{|l|}{ SST- $170^{\circ} \mathrm{C}-10 \mathrm{~s}$} \\
\hline 0 & $2.32 \pm 0.05^{\mathrm{A}, \mathrm{a}}$ & $0.65 \pm 0.00 \mathrm{~A}, \mathrm{a}$ & $2.83 \pm 0.06^{\mathrm{A}, \mathrm{a}}$ & $7.33 \pm 0.10^{\mathrm{B}, \mathrm{a}, \mathrm{b}}$ & $1.43 \pm 0.02 \mathrm{~A}, \mathrm{a}$ & $2.97 \pm 0.05^{\mathrm{A}, \mathrm{a}}$ & $11.58 \pm 0.16^{\mathrm{A}, \mathrm{a}, \mathrm{b}}$ & $14.55 \pm 0.21^{\mathrm{A}, \mathrm{a}}$ \\
\hline 6 & $2.28 \pm 0.13^{\mathrm{A}, \mathrm{a}, \mathrm{b}}$ & $0.65 \pm 0.01 \mathrm{~A}, \mathrm{a}$ & $2.69 \pm 0.10^{\mathrm{A}, \mathrm{b}}$ & $7.17 \pm 0.44^{\mathrm{A}, \mathrm{b}}$ & $1.37 \pm 0.03^{\mathrm{A}, \mathrm{b}}$ & $2.93 \pm 0.14^{\mathrm{A}, \mathrm{a}, \mathrm{b}}$ & $11.24 \pm 0.58^{\mathrm{A}, \mathrm{a}, \mathrm{b}}$ & $14.16 \pm 0.72^{\mathrm{A}, \mathrm{a}, \mathrm{b}}$ \\
\hline 9 & $2.31 \pm 0.02^{\mathrm{B}, \mathrm{a}}$ & $0.53 \pm 0.00^{\mathrm{B}, \mathrm{c}}$ & $2.68 \pm 0.00^{\mathrm{B}, \mathrm{a}, \mathrm{b}}$ & $7.78 \pm 0.07^{\mathrm{B}, \mathrm{a}}$ & $1.19 \pm 0.01 \mathrm{~A}, \mathrm{c}$ & $2.84 \pm 0.02^{\mathrm{B}, \mathrm{b}}$ & $11.65 \pm 0.07^{\mathrm{B}, \mathrm{a}}$ & $14.49 \pm 0.09$ B,a \\
\hline 12 & $2.18 \pm 0.02^{C, b}$ & $0.53 \pm 0.00^{\mathrm{B}, \mathrm{c}}$ & $2.56 \pm 0.01^{\mathrm{B}, \mathrm{b}}$ & $7.24 \pm 0.05^{\mathrm{C}, \mathrm{b}}$ & $1.16 \pm 0.01^{\mathrm{B}, \mathrm{d}}$ & $2.71 \pm 0.02^{\mathrm{C}, \mathrm{c}}$ & $10.96 \pm 0.07^{C, b}$ & $13.67 \pm 0.08^{\mathrm{C}, \mathrm{b}}$ \\
\hline \multicolumn{9}{|l|}{ SST- $190^{\circ} \mathrm{C}-5 \mathrm{~s}$} \\
\hline 0 & $2.30 \pm 0.09^{\mathrm{A}, \mathrm{b}}$ & $0.64 \pm 0.01^{\mathrm{A}, \mathrm{a}}$ & $2.78 \pm 0.12^{\mathrm{A}, \mathrm{b}}$ & $7.95 \pm 0.53^{\mathrm{A}, \mathrm{a}, \mathrm{b}}$ & $1.43 \pm 0.03^{\mathrm{A}, \mathrm{a}}$ & $2.94 \pm 0.11^{\mathrm{A}, \mathrm{c}}$ & $12.15 \pm 0.68^{\mathrm{A}, \mathrm{a}}$ & $15.10 \pm 0.79^{\mathrm{A}, \mathrm{a}}$ \\
\hline 3 & $2.38 \pm 0.07^{\mathrm{A}, \mathrm{b}}$ & $0.64 \pm 0.01^{\mathrm{A}, \mathrm{a}}$ & $2.77 \pm 0.07^{\mathrm{A}, \mathrm{b}}$ & $7.86 \pm 0.25^{\mathrm{A}, \mathrm{a}, \mathrm{b}}$ & $1.41 \pm 0.01^{\mathrm{A}, \mathrm{a}, \mathrm{b}}$ & $3.03 \pm 0.08^{\mathrm{A}, \mathrm{b}, \mathrm{c}}$ & $12.05 \pm 0.33^{\mathrm{A}, \mathrm{a}}$ & $15.08 \pm 0.41^{\mathrm{A}, \mathrm{a}}$ \\
\hline 6 & $2.42 \pm 0.01 \mathrm{~A}, \mathrm{~b}$ & $0.65 \pm 0.00^{\mathrm{A}, \mathrm{a}}$ & $2.79 \pm 0.01^{\mathrm{A}, \mathrm{b}}$ & $7.70 \pm 0.01 \mathrm{~A}, \mathrm{a}, \mathrm{b}$ & $1.40 \pm 0.01 \mathrm{~A}, \mathrm{~b}$ & $3.07 \pm 0.01^{\mathrm{A}, \mathrm{b}}$ & $11.90 \pm 0.00^{\mathrm{A}, \mathrm{a}}$ & $14.97 \pm 0.01^{\mathrm{A}, \mathrm{a}}$ \\
\hline 9 & $2.41 \pm 0.01 \mathrm{~A}, \mathrm{~b}$ & $0.55 \pm 0.01 \mathrm{~A}, \mathrm{~b}$ & $2.75 \pm 0.01^{\mathrm{A}, \mathrm{b}}$ & $8.23 \pm 0.06^{\mathrm{A}, \mathrm{a}}$ & $1.20 \pm 0.00 \mathrm{~A}, \mathrm{~d}$ & $2.96 \pm 0.01^{\mathrm{A}, \mathrm{b}, \mathrm{c}}$ & $12.19 \pm 0.05^{\mathrm{A}, \mathrm{a}}$ & $15.15 \pm 0.07^{\mathrm{A}, \mathrm{a}}$ \\
\hline 12 & $2.48 \pm 0.00^{\mathrm{A}, \mathrm{a}}$ & $0.55 \pm 0.00^{\mathrm{A}, \mathrm{b}}$ & $3.05 \pm 0.02 \mathrm{~A}, \mathrm{a}$ & $7.51 \pm 0.02^{\mathrm{A}, \mathrm{b}}$ & $1.26 \pm 0.01^{\mathrm{A}, \mathrm{c}}$ & $3.03 \pm 0.00 \mathrm{~A}, \mathrm{a}$ & $11.82 \pm 0.01 \mathrm{~A}, \mathrm{a}$ & $14.85 \pm 0.01^{\mathrm{A}, \mathrm{a}}$ \\
\hline
\end{tabular}

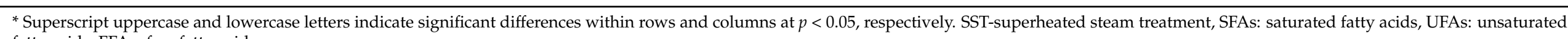
fatty acids, FFAs: free fatty acids. 


\subsection{Changes of Tocopherols and Tocotrienols Content in Dried Whole Wheat Noodles during Storage}

The content of tocols, including two tocopherols ( $\alpha$ - and $\beta$-tocopherol) and four tocotrienols $(\alpha-, \beta-, \gamma-$ and $\delta$-tocotrienol), in control group of DWWN was $7.7 \mu \mathrm{g} / \mathrm{g}$ (Table 5), in which $\alpha$-tocopherol had the highest content, with a content of $3.1 \mu \mathrm{g} / \mathrm{g}$, followed by $\beta$-tocotrienol, with a content of $1.9 \mu \mathrm{g} / \mathrm{g}$. In general, the content of tocotrienols in DWWN was higher than tocopherols, which was consistent with the result of Lampi et al. [6] and Shadyro et al. [47]. As natural antioxidants, tocols can act as a hydrogen donor and combine with hydroperoxide radicals (ROO•) to form hydrogen peroxide, which can prevent lipid autoxidation by inhibiting the peroxidation of UFAs and other compounds $[7,48]$. The combination rate of tocols and $\mathrm{ROO} \bullet$ is far higher than that of UFAs and ROO•. One tocopherol molecule can even protect $10^{4}-10^{9}$ UFA molecules $[49,50]$. Therefore, the content of tocols can reflect the degree of lipid auto-oxidation of DWWN during storage. The tocols content of DWWN made from SST-processed WWF was significantly higher than that of control DWWN $(p<0.05)$, and the content in the SST- $155^{\circ} \mathrm{C}-10 \mathrm{~s}$, SST-170 ${ }^{\circ} \mathrm{C}-10 \mathrm{~s}$, SST- $190{ }^{\circ} \mathrm{C}-5 \mathrm{~s}$ group was $1.4,1.6$ and 1.6-fold than that of the control group. This indicated that the SST can effectively inhibit the consumption of tocols during production of DWWN.

The content of tocopherols and tocotrienols in DWWN decreased significantly $(p<0.05)$ during storage. After 12 weeks of storage, the control group, SST-155 ${ }^{\circ} \mathrm{C}-10 \mathrm{~s}$, SST-170 ${ }^{\circ} \mathrm{C}-10 \mathrm{~s}$, SST- $190{ }^{\circ} \mathrm{C}-5 \mathrm{~s}$ group decreased by $3.2,6.1,6.3,1.3 \mu \mathrm{g} / \mathrm{g}$, respectively. The high reduction of tocols in groups of SST- $155^{\circ} \mathrm{C}-10 \mathrm{~s}$ and SST- $170{ }^{\circ} \mathrm{C}-10 \mathrm{~s}$ may be due to the long treatment time, and also the high temperature promoted lipid auto-oxidation and thus produced more free radicals. The content of tocols decreases by scavenging free radicals during storage [51]. Besides, the SST- $155^{\circ} \mathrm{C}-10 \mathrm{~s}$ and SST- $170{ }^{\circ} \mathrm{C}-10 \mathrm{~s}$ group had less reduction in UFA during storage (Table 4), most likely because the tocols were consumed in the reaction, which slowed the lipid degradation process. After storage for 12 weeks, the tocols content of the SST- $155^{\circ} \mathrm{C}-10 \mathrm{~s}$, SST- $170{ }^{\circ} \mathrm{C}-10 \mathrm{~s}$, SST- $190{ }^{\circ} \mathrm{C}-5$ s group was 1.0, 1.3 and 2.4-fold compared to the control group, of which the tocols content in SST $-190{ }^{\circ} \mathrm{C}-5 \mathrm{~s}$ was the highest. It indicated that the tocopherols and tocotrienols of the SST- $190{ }^{\circ} \mathrm{C}-5 \mathrm{~s}$ group were the most stable during storage.

\subsection{Changes of Volatile Compounds in Dried Whole Wheat Noodles during Storage}

As shown in Figure 3, the volatile compounds detected in DWWN mainly consisted of aldehydes, ketones, acid esters, alcohols, alkanes, heterocyclics and aromatics. Volatile compounds are mostly the products of lipid oxidation. Lipid oxidation produces hydroperoxides, which are chemically unstable and easily broken down into smaller volatiles through different pathways [52]. The relative content and type of volatile compounds in DWWN were affected by the heat treatment and storage time. As the storage progresses, the relative content of alkanes and aromatics in all sample groups decreased, while the relative content of alcohols, acid esters, ketones, aldehydes, and heterocyclics increased (Figure 3). The relative content of aldehydes in the control group decreased, while the content of heterocyclics increased (Figure 3A). The volatile compounds in the SST- $155{ }^{\circ} \mathrm{C}-10 \mathrm{~s}, \mathrm{SST}-170{ }^{\circ} \mathrm{C}-10 \mathrm{~s}, \mathrm{SST}-190{ }^{\circ} \mathrm{C}-5 \mathrm{~s}$ groups were mainly aldehydes and heterocyclics (Figure 3B-D), but the relative content of aldehydes and heterocyclics in the SST- $190{ }^{\circ} \mathrm{C}-5 \mathrm{~s}$ group was lower than other SST groups. Among them, hexanal in the aldehydes has the taste of grass and animal fat, which was a first-class product of autooxidation of linoleic acid. When their concentration increases, it seriously affects the flavor of food [53]. The 2-pentylfuran in the heterocyclic ring is generated by the cleavage of linoleic acid and has the flavor of nutty, beany, and buttery [54]. Because of its low threshold and great contribution to bad odor, hexanal and 2-pentylfuran were selected as the marker products of lipid oxidation [26,45]. 


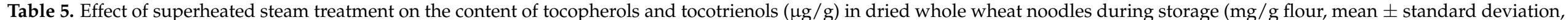
$n=3)$.

\begin{tabular}{|c|c|c|c|c|c|c|c|c|c|c|}
\hline \multirow{2}{*}{ Sample } & \multirow{2}{*}{$\begin{array}{l}\text { Storage Time } \\
\text { (Weeks) }\end{array}$} & \multicolumn{9}{|c|}{ Tocopherols and Tocotrienols $(\mu \mathrm{g} / \mathrm{g})$} \\
\hline & & $\alpha$-Tocopherol & $\alpha$-Tocotrienol & $\beta$-Tocopherol & $\beta$-Tocotrienol & $\gamma$-Tocotrienol & $\delta$-Tocotrienol & Tocopherols & Tocotrienols & Tocols \\
\hline \multirow{5}{*}{ Control } & 0 & $3.11 \pm 0.12$ & $0.59 \pm 0.03$ & $0.53 \pm 0.05$ & $1.89 \pm 0.22$ & $1.24 \pm 0.10$ & $0.37 \pm 0.00$ & $3.64 \pm 0.08^{\mathrm{B}, \mathrm{a}, *}$ & $4.09 \pm 0.35^{\mathrm{B}, \mathrm{a}}$ & $7.73 \pm 0.28^{\mathrm{B}, \mathrm{a}}$ \\
\hline & 3 & $1.92 \pm 0.18$ & $0.40 \pm 0.01$ & $0.54 \pm 0.03$ & $1.53 \pm 0.19$ & $0.62 \pm 0.13$ & $0.15 \pm 0.03$ & $2.47 \pm 0.21^{\mathrm{B}, \mathrm{b}}$ & $2.70 \pm 0.11^{C, b}$ & $5.16 \pm 0.32^{C, b}$ \\
\hline & 6 & $2.04 \pm 0.08$ & $0.43 \pm 0.01$ & $0.37 \pm 0.01$ & $1.80 \pm 0.02$ & $0.41 \pm 0.01$ & nd & $2.41 \pm 0.09^{\mathrm{D}, \mathrm{b}}$ & $2.63 \pm 0.01^{\mathrm{D}, \mathrm{b}}$ & $5.04 \pm 0.10^{\mathrm{D}, \mathrm{b}, \mathrm{c}}$ \\
\hline & 9 & $1.68 \pm 0.27$ & $0.48 \pm 0.03$ & $0.51 \pm 0.04$ & $1.48 \pm 0.14$ & $0.36 \pm 0.03$ & $0.23 \pm 0.03$ & $2.19 \pm 0.25^{\mathrm{C}, \mathrm{b}, \mathrm{c}}$ & $2.55 \pm 0.12^{C, b}$ & $4.74 \pm 0.13^{\mathrm{C}, \mathrm{c}, \mathrm{d}}$ \\
\hline & 12 & $1.25 \pm 0.03$ & $0.81 \pm 0.01$ & $0.62 \pm 0.10$ & $1.43 \pm 0.08$ & $0.43 \pm 0.00$ & nd & $1.86 \pm 0.13^{\mathrm{C}, \mathrm{c}}$ & $2.67 \pm 0.07 \mathrm{C}, \mathrm{b}$ & $4.53 \pm 0.15^{\mathrm{C}, \mathrm{d}}$ \\
\hline \multirow{5}{*}{$\begin{array}{c}\text { SST- } \\
155^{\circ} \mathrm{C}-10 \mathrm{~s}\end{array}$} & 0 & $2.77 \pm 0.27$ & $0.62 \pm 0.20$ & $0.98 \pm 0.10$ & $4.53 \pm 0.68$ & $1.45 \pm 0.78$ & $0.37 \pm 0.04$ & $3.75 \pm 0.28^{\mathrm{B}, \mathrm{a}}$ & $6.98 \pm 1.68^{\mathrm{A}, \mathrm{a}}$ & $10.72 \pm 1.71^{\mathrm{A}, \mathrm{a}}$ \\
\hline & 3 & $1.52 \pm 0.02$ & $0.37 \pm 0.01$ & $0.68 \pm 0.12$ & $2.60 \pm 0.62$ & $0.53 \pm 0.05$ & $0.18 \pm 0.02$ & $2.20 \pm 0.10^{\mathrm{A}, \mathrm{B}, \mathrm{c}}$ & $3.68 \pm 0.66^{\mathrm{C}, \mathrm{b}}$ & $5.87 \pm 0.75^{\mathrm{C}, \mathrm{b}}$ \\
\hline & 6 & $2.13 \pm 0.06$ & $1.03 \pm 0.05$ & $0.53 \pm 0.08$ & $1.51 \pm 0.02$ & $0.45 \pm 0.01$ & nd & $2.67 \pm 0.05^{\mathrm{C}, \mathrm{b}}$ & $3.00 \pm 0.02^{C, b}$ & $5.67 \pm 0.06^{\mathrm{C}, \mathrm{b}}$ \\
\hline & 9 & $2.17 \pm 0.27$ & $0.37 \pm 0.04$ & $0.34 \pm 0.02$ & $1.31 \pm 0.05$ & $0.27 \pm 0.00$ & $0.22 \pm 0.02$ & $2.50 \pm 0.25^{\mathrm{B}, \mathrm{C}, \mathrm{b}}$ & $2.16 \pm 0.02^{C, b}$ & $4.66 \pm 0.23^{C, b}$ \\
\hline & 12 & $1.73 \pm 0.02$ & $0.47 \pm 0.00$ & $0.63 \pm 0.03$ & $1.46 \pm 0.08$ & $0.32 \pm 0.00$ & nd & $2.36 \pm 0.01^{\mathrm{B}, \mathrm{b}, \mathrm{c}}$ & $2.25 \pm 0.08^{\mathrm{D}, \mathrm{b}}$ & $4.61 \pm 0.09^{\mathrm{C}, \mathrm{b}}$ \\
\hline \multirow{5}{*}{$\begin{array}{c}\text { SST- } \\
170^{\circ} \mathrm{C}-10 \mathrm{~s}\end{array}$} & 0 & $2.88 \pm 0.19$ & $0.48 \pm 0.02$ & $1.35 \pm 0.12$ & $6.46 \pm 0.66$ & $0.55 \pm 0.06$ & $0.33 \pm 0.01$ & $4.24 \pm 0.26^{\mathrm{A}, \mathrm{a}}$ & $7.47 \pm 0.77^{\mathrm{A}, \mathrm{a}}$ & $12.05 \pm 0.78^{\mathrm{A}, \mathrm{a}}$ \\
\hline & 3 & $1.34 \pm 0.04$ & $0.56 \pm 0.16$ & $0.74 \pm 0.03$ & $3.67 \pm 0.55$ & $1.13 \pm 0.16$ & $0.13 \pm 0.00$ & $2.08 \pm 0.07^{\mathrm{C}, \mathrm{d}}$ & $5.48 \pm 0.55^{\mathrm{B}, \mathrm{b}}$ & $7.56 \pm 0.47^{\mathrm{B}, \mathrm{b}}$ \\
\hline & 6 & $2.59 \pm 0.08$ & $1.02 \pm 0.07$ & $0.51 \pm 0.12$ & $1.74 \pm 0.02$ & $0.47 \pm 0.02$ & nd & $3.10 \pm 0.18^{\mathrm{B}, \mathrm{b}}$ & $3.23 \pm 0.06^{\mathrm{B}, \mathrm{c}}$ & $6.33 \pm 0.15^{\mathrm{B}, \mathrm{c}}$ \\
\hline & 9 & $2.23 \pm 0.23$ & $0.32 \pm 0.03$ & $0.54 \pm 0.02$ & $2.31 \pm 0.02$ & $0.30 \pm 0.05$ & $0.24 \pm 0.01$ & $2.77 \pm 0.25^{\mathrm{B}, \mathrm{c}}$ & $3.17 \pm 0.01^{\mathrm{B}, \mathrm{c}}$ & $5.94 \pm 0.26^{\mathrm{B}, \mathrm{c}}$ \\
\hline & 12 & $1.78 \pm 0.02$ & $1.16 \pm 0.10$ & $0.66 \pm 0.03$ & $1.68 \pm 0.05$ & $0.47 \pm 0.02$ & nd & $2.44 \pm 0.04^{\mathrm{B}, \mathrm{c}, \mathrm{d}}$ & $3.31 \pm 0.16^{\mathrm{B}, \mathrm{c}}$ & $5.75 \pm 0.13^{\mathrm{B}, \mathrm{c}}$ \\
\hline \multirow{3}{*}{$\begin{array}{c}\text { SST- } \\
190^{\circ} \mathrm{C}-5 \mathrm{~s}\end{array}$} & 0 & $2.97 \pm 0.10$ & $0.53 \pm 0.03$ & $1.28 \pm 0.03$ & $5.94 \pm 0.12$ & $1.00 \pm 0.19$ & $0.36 \pm 0.01$ & $4.25 \pm 0.07^{\mathrm{A}, \mathrm{a}}$ & $7.83 \pm 0.16^{\mathrm{A}, \mathrm{b}}$ & $12.08 \pm 0.18^{\mathrm{A}, \mathrm{a}}$ \\
\hline & 3 & $1.66 \pm 0.01$ & $1.13 \pm 0.01$ & $1.56 \pm 0.01$ & $5.70 \pm 0.03$ & $1.33 \pm 0.03$ & $0.29 \pm 0.01$ & $3.22 \pm 0.02^{\mathrm{A}, \mathrm{d}}$ & $8.45 \pm 0.08^{\mathrm{A}, \mathrm{a}}$ & $11.67 \pm 0.07^{\mathrm{A}, \mathrm{b}}$ \\
\hline & 12 & $1.75 \pm 0.02$ & $1.09 \pm 0.02$ & $1.92 \pm 0.04$ & $5.47 \pm 0.03$ & $0.54 \pm 0.07$ & nd & $3.67 \pm 0.06^{\mathrm{A}, \mathrm{c}}$ & $7.09 \pm 0.05^{\mathrm{A}, \mathrm{d}}$ & $10.76 \pm 0.08^{\mathrm{A}, \mathrm{d}}$ \\
\hline
\end{tabular}

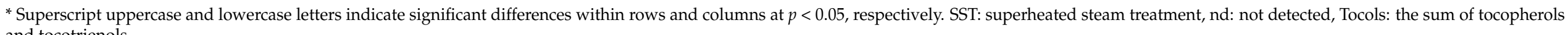
and tocotrienols. 

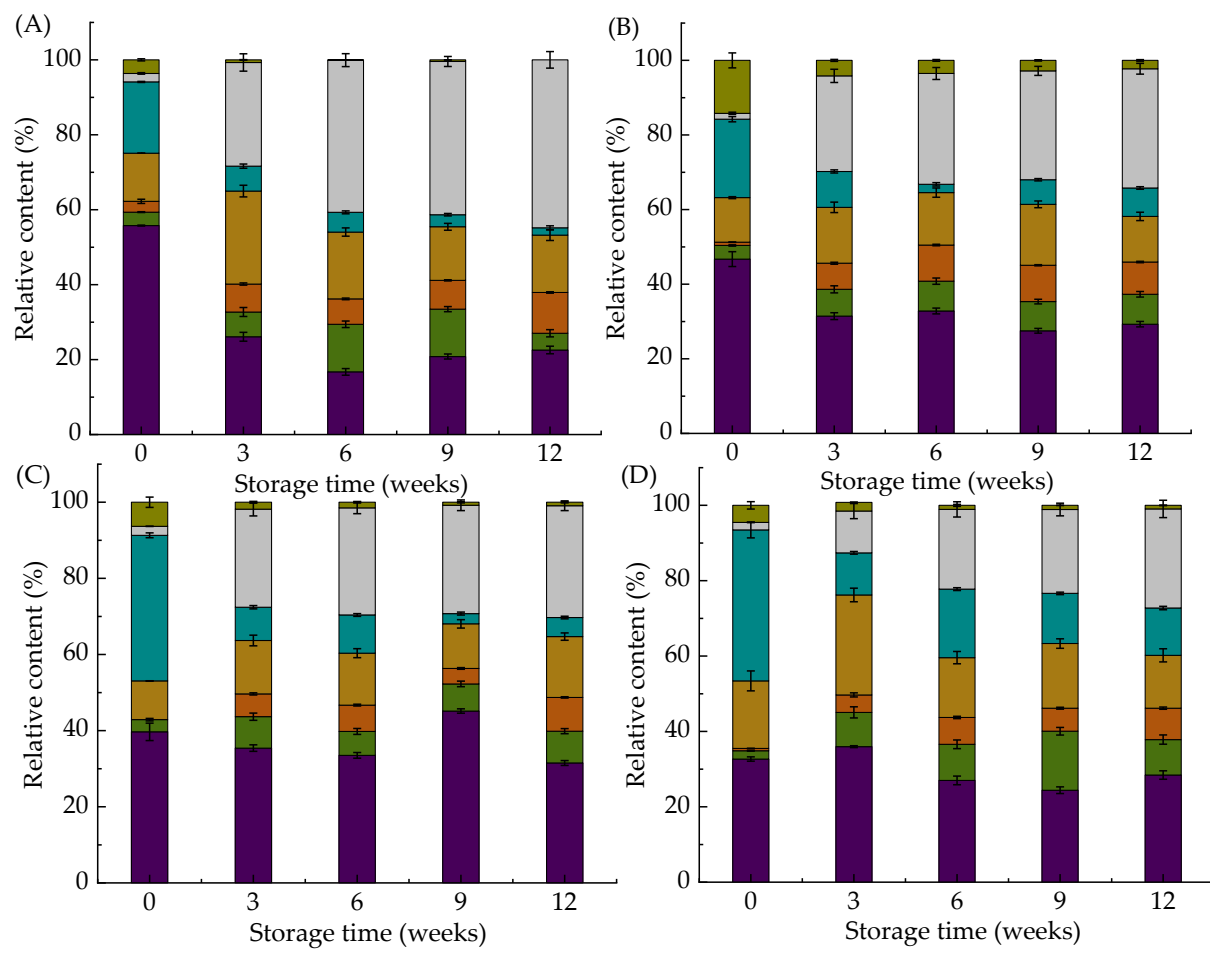

$\square$ Aromatics $\square$ Heterocycles

Alkanes

Alcohols

Ketones

Acid esters

Aldehyde

Figure 3. Effect of superheated steam treatment on relative content of volatile compounds in dried whole wheat noodles during storage. (A) Control, (B) SST at $155^{\circ} \mathrm{C}$ for $10 \mathrm{~s}$, (C): SST at $170{ }^{\circ} \mathrm{C}$ for $10 \mathrm{~s}$, (D) SST at $190{ }^{\circ} \mathrm{C}$ for $5 \mathrm{~s}$. SST: superheated steam treatment.

The contents of hexanal, 2-pentylfuran, and total volatile compounds in all sample groups gradually increased during storage (Figure 4). As shown in Figure 4A,B, during storage, the content of hexanal in the SST group was higher than that of the control group, and the content of 2-pentylfuran was lower than that of the control group. After 12 weeks of storage, the content of hexanal in the SST- $155^{\circ} \mathrm{C}-10 \mathrm{~s}$, SST- $170{ }^{\circ} \mathrm{C}-10 \mathrm{~s}$, SST- $190{ }^{\circ} \mathrm{C}-5 \mathrm{~s}$ group was 1.9, 2.3, 1-fold compared to the control group (Figure 4A), the content of 2-pentylfuran was $0.7,0.6$, and 0.4 -fold that of the control group, respectively (Figure 4B). Hexanal was mainly produced by the cleavage of 13-hydroperoxide (13- $\mathrm{ROOH}$ ) by the auto-oxidation of UFAs, and 2-pentylfuran was mainly produced by the cleavage of 9-ROOH by the enzymatic oxidation of UFAs $[26,45,55]$. LOX was conducive to the formation of 9-ROOH, the amount of 9-ROOH produced was over 7-fold that of $13-\mathrm{ROOH}$ when the LOX was active, while the ratio of these two hydroperoxides in auto-oxidation was equivalent $[45,56]$. This indicated that LOX was passivated after the SST, the enzymatic oxidation pathway was inhibited and the auto-oxidation pathway was promoted. However, the enzymatic oxidation pathway of the SST- $190{ }^{\circ} \mathrm{C}-5 \mathrm{~s}$ group was inhibited while the auto-oxidation pathway was not significantly different from the control group. In addition, the total volatile compounds in the SST groups were lower than the control group at the initial stage of storage. After 12 weeks of storage, the total volatile compounds of the SST- $190{ }^{\circ} \mathrm{C}-5 \mathrm{~s}$ group was lower than that of the SST- $155^{\circ} \mathrm{C}-10 \mathrm{~s}$, SST- $170{ }^{\circ} \mathrm{C}-10 \mathrm{~s}$ group and control group. Besides, the total compounds of the SST- $190^{\circ} \mathrm{C}-5 \mathrm{~s}$ group was only 0.7 -fold compared to the control group (Figure 4C). This indicated that the SST can significantly inhibit the generation of volatile compounds during the process and storage of DWWN, and the SST- $190{ }^{\circ} \mathrm{C}-5 \mathrm{~s}$ condition was the most effective. 

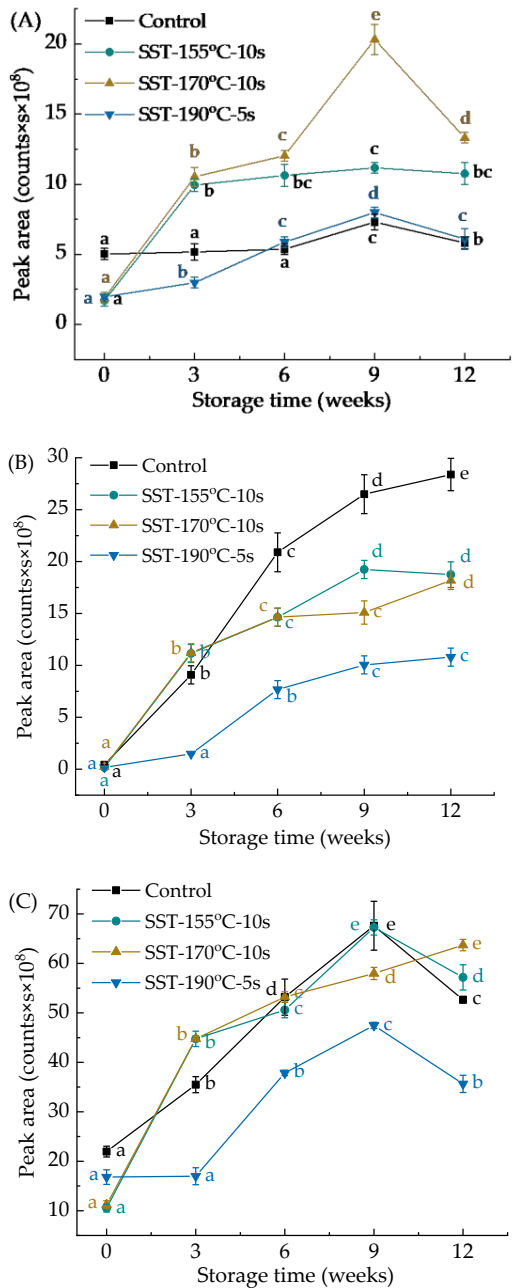

Figure 4. Effect of superheated steam treatment on peak area of volatile compounds in dried whole wheat noodles during storage. (A) The peak area of Hexanal, (B) the peak area of 2-pentylfuran, (C) total volatile compounds. The lowercase letters in the column chart indicate the significant difference of the same sample in different storage time at $p<0.05$. SST: superheated steam treatment.

\section{Conclusions}

The SST significantly inhibited the lipid hydrolysis and oxidation during the process and storage of DWWN. Compared with the control group of DWWN, the lipase and POD in the SST groups were completely passivated, and the LOX activity was reduced by more than $67.6 \%$. During storage, the activities of lipase, LOX and POD were not detected in the SST-processed DWWN. The SST significantly inhibited the increase of fatty acid value, the degradation of UFAs, the consumption of tocols, and the generation of volatile compounds during the process and storage of DWWN. Among them, SST- $190{ }^{\circ} \mathrm{C}-5 \mathrm{~s}$ had the best inhibitory effect. In addition, the SST might promote auto-oxidation while inhibiting the enzymatic hydrolysis and enzymatic oxidation pathways, which depended on the treatment time of the SST. Therefore, SST is expected to be a method to improve the lipid stability of whole wheat products.

Author Contributions: Conceptualization, W.-T.J.; methodology, W.-T.J. and Z.Y.; software, W.-T.J.; validation, W.-T.J.; formal analysis, W.-T.J.; investigation, W.-T.J.; resources, Z.Y., X.-N.G. and K.-X.Z.; data curation, W.-T.J.; writing — original draft preparation, W.-T.J.; writing—review and editing, W.-T.J., Z.Y. and K.-X.Z.; visualization, W.-T.J.; supervision, Z.Y., X.-N.G. and K.-X.Z.; project administration, K.-X.Z.; funding acquisition, K.-X.Z. All authors have read and agreed to the published version of the manuscript. 
Funding: This work was financed by the National Key Research and Development Program of China (No. 2018YFD0401003), the Fundamental Research Funds for the Central Universities (JUSRP121003), and the National First-Class Discipline Program of Food Science and Technology (JUFSTR20180204).

Data Availability Statement: The data that support the findings of this study are available on request from the corresponding author. The data are not publicly available due to privacy or ethical restrictions.

Conflicts of Interest: The authors declare no conflict of interest.

\section{References}

1. Reynolds, A.; Mann, J.; Cummings, J.; Winter, N.; Mete, E.; Morenga, L.T. Carbohydrate quality and human health: A series of systematic reviews and meta-analyses. Lancet 2019, 393, 434-445. [CrossRef]

2. Guo, X.N.; Wu, S.H.; Zhu, K.X. Effect of superheated steam treatment on quality characteristics of whole wheat flour and storage stability of semi-dried whole wheat noodle. Food Chem. 2020, 322, 126738. [CrossRef] [PubMed]

3. Zhu, Y.D.; Sang, S.M. Phytochemicals in whole grain wheat and their health-promoting effects. Mol. Nutr. Food Res. 2017, 61, 1600852. [CrossRef] [PubMed]

4. Niu, M.; Hou, G.G. Whole wheat noodle: Processing, quality improvement, and nutritional and health benefits. Cereal Chem. 2019, 96, 23-33. [CrossRef]

5. Luthria, D.L.; Lu, Y.J.; John, K.M.M. Bioactive phytochemicals in wheat: Extraction, analysis, processing, and functional properties. J. Funct. Foods 2015, 18, 910-925. [CrossRef]

6. Lampi, A.M.; Nurmi, T.; Ollilainen, V.; Piironen, V. Tocopherols and tocotrienols in wheat genotypes in the HEALTHGRAIN Diversity Screen. J. Agric. Food Chem. 2008, 56, 9716-9721. [CrossRef] [PubMed]

7. Mufari, J.R.; Gorostegui, H.; Miranda, P.; Bergesse, A.E.; Calandri, E. Oxidative Stability and Characterization of Quinoa Oil Extracted from Wholemeal and Germ Flours. J. Am. Oil Chem. Soc. 2020, 97, 12308. [CrossRef]

8. Peh, H.Y.; Tan, W.S.D.; Liao, W.; Wong, W.S.F. Vitamin E therapy beyond cancer: Tocopherol versus tocotrienol. Pharmacol. Ther. 2016, 162, 152-169. [CrossRef]

9. Yu, X.L.; Wang, Z.H.; Zhang, Y.Q.; Wadood, S.A.; Wei, Y.M. Study on the water state and distribution of Chinese dried noodles during the drying process. J. Food Eng. 2018, 233, 81-87. [CrossRef]

10. Doblado-Maldonado, A.F.; Pike, O.A.; Sweley, J.C.; Rose, D.J. Key issues and challenges in whole wheat flour milling and storage. J. Cereal Sci. 2012, 56, 119-126. [CrossRef]

11. Poudel, R.; Rose, D.J. Changes in enzymatic activities and functionality of whole wheat flour due to steaming of wheat kernels. Food Chem. 2018, 263, 315-320. [CrossRef]

12. Ling, B.; Lyng, J.G.; Wang, S. Effects of hot air-assisted radio frequency heating on enzyme inactivation, lipid stability and product quality of rice bran. LWT-Food Sci. Technol. 2018, 91, 453-459. [CrossRef]

13. Lei, L.; Wen, W.; Zhang, R.; Wei, Z.; Deng, Y.; Xiao, J.; Zhang, M. Complex enzyme hydrolysis releases antioxidative phenolics from rice bran. Food Chem. 2017, 214, 1-8. [CrossRef]

14. Bhat, N.A.; Wani, I.A.; Hamdani, A.M.; Gani, A.; Masoodi, F.A. Physicochemical properties of whole wheat flour as affected by gamma irradiation. LWT-Food Sci. Technol. 2016, 71, 175-183. [CrossRef]

15. Hu, Y.; Wang, L.; Li, Z. Superheated steam treatment on wheat bran: Enzymes inactivation and nutritional attributes retention. LWT-Food Sci. Technol. 2018, 91, 446-452. [CrossRef]

16. Wu, J.; McClements, D.J.; Chen, J.; Liu, W.; Luo, S.; Liu, C. Improvement in storage stability of lightly milled rice using superheated steam processing. J. Cereal Sci. 2016, 71, 130-137. [CrossRef]

17. Alfy, A.; Kiran, B.V.; Jeevitha, G.C.; Hebbar, H.U. Recent developments in superheated steam processing of foods-A review. Crit. Rev. Food Sci. Nutr. 2016, 56, 2191-2208. [CrossRef]

18. Head, D.; Cenkowski, S.; Arntfield, S.; Henderson, K. Storage stability of oat groats processed commercially and with superheated steam. LWT-Food Sci. Technol. 2011, 44, 261-268. [CrossRef]

19. Liu, C.; Yan, X.Y.; Xu, X.F.; Guo, B.Z.; Yang, R.; Chen, J.; Zhong, Y.J.; Luo, S.J.; Xu, J.G.; Wu, J.Y. Changes in Granular Swelling and Rheological Properties of Food Crop Starches Modified by Superheated Steam. Starch-Starke 2019, 71, 1800132. [CrossRef]

20. Hu, Y.M.; Nie, W.; Hu, X.Z.; Li, Z.G. Microbial decontamination of wheat grain with superheated steam. Food Control 2016, 62, 264-269. [CrossRef]

21. Sehrawat, R.; Nema, P.K.; Kaur, B.P. Effect of superheated steam drying on properties of foodstuffs and kinetic modeling. Innov. Food Sci. Emerg. Technol. 2016, 34, 285-301. [CrossRef]

22. American Association of Cereal Chemists. American Association of Cereal Chemists Approved Methods, 10th ed.; AACC: St. Paul, MN, USA, 2000.

23. Cai, J.; Xie, Y.; Song, B.; Wang, Y.; Zhang, Z.; Feng, Y. Fervidobacterium changbaicum Lip1: Identification, cloning, and characterization of the thermophilic lipase as a new member of bacterial lipase family V. Appl. Microbiol. Biotechnol. 2011, 89, 1463-1473. [CrossRef] [PubMed]

24. Cato, L.; Halmos, A.L.; Small, D.M. Measurement of lipoxygenase in Australian white wheat flour: The effect of lipoxygenase on the quality properties of white salted noodles. J. Sci. Food Agr. 2010, 86, 1670-1678. [CrossRef] 
25. Sessa, D.J.; Anderson, R.L. Soybean peroxidases: Purification and some properties. J. Agric. Food Chem. 1981, $29,960-965$. [CrossRef]

26. Jiang, Z.Q.; Pulkkinen, M.; Wang, Y.J.; Lampi, A.M.; Stoddard, F.L.; Salovaara, H.; Piironen, V.; Sontag-Strohm, T. Faba bean flavour and technological property improvement by thermal pre-treatments. LWT-Food Sci. Technol. 2016, 68, 295-305. [CrossRef]

27. Yao, L.; Schaich, K.M. Accelerated solvent extraction improves efficiency of lipid removal from dry pet food while limiting lipid oxidation. J. Am. Oil Chem. Soc. 2014, 92, 141-151. [CrossRef]

28. Shin, T.S.; Godber, J.S. Changes of endogenous antioxidants and fatty acid composition in irradiated rice bran during storage. J. Agric. Food Chem. 1996, 44, 567-573. [CrossRef]

29. Paradiso, V.M.; Summo, C.; Trani, A.; Caponio, F. An effort to improve the shelf life of breakfast cereals using natural mixed tocopherols. J. Cereal Sci. 2008, 47, 322-330. [CrossRef]

30. Zhao, S.; Xiong, S.; Qiu, C.; Xu, Y. Effect of microwaves on rice quality. J. Stored Prod. Res. 2007, 43, 496-502. [CrossRef]

31. Wu, J.Y.; Chen, J.; Liu, W.; Liu, C.M.; Zhong, Y.J.; Luo, D.W.; Li, Z.Q.; Huang, Z.L. Selective peroxidase inactivation of lightly milled rice by superheated steam. J. Cereal Sci. 2014, 60, 623-630. [CrossRef]

32. Akyol, C.; Alpas, H.; Bayindirli, A. Inactivation of peroxidase and lipoxygenase in carrots, green beans, and green peas by combination of high hydrostatic pressure and mild heat treatment. Eur. Food Res. Technol. 2006, 224, 171-176. [CrossRef]

33. Lusena, C.V.; McFarlane, W.D. Studies on the processing of wheat germ. Can. J. Res. 1945, 23, 202-211. [CrossRef]

34. Xu, B.; Zhou, S.L.; Miao, W.J.; Gao, C.; Cai, M.J.; Dong, Y. Study on the stabilization effect of continuous microwave on wheat germ. J. Food Eng. 2013, 117, 1-7. [CrossRef]

35. Kapranchikov, V.S.; Zherebtsov, N.A.; Popova, T.N. Purification and Characterization of Lipase from Wheat (Triticum aestivum L.) Germ. Appl. Biochem. Micro. 2004, 40, 84-88. [CrossRef]

36. Wallace, J.M.; Wheeler, E.L. Two lipoxygenase isoenzymes and an activator in wheat germ. Phytochemistry 1979, 18, 389-393 [CrossRef]

37. Tome, D.; Nicolas, J.; Drapron, R. Influence of water activity on the reaction catalyzed by polyphenoloxidase (E.C.1.14.18.1.) from mushrooms in organic liquid media. LWT Lebensmitt Wissensch Technol. 1978, 11, 38-41.

38. Lai, H.M.; Hwang, S.C. Water status of cooked white salted noodles evaluated by MRI. Food Res. Int. 2004, 37, 957-966. [CrossRef]

39. Xu, B.; Miao, W.J.; Hu, Q.S.; Gao, C.; Dong, Y. A modified colorimetric method for determining the activity of wheat germ lipase in low-aqueous media. Qual. Assur. Saf. Crops 2013, 5, 113-118. [CrossRef]

40. Feussner, I.; Wasternack, C. The lipoxygenase pathway. Annu. Rev. Plant Biol. 2002, 53, 275-297. [CrossRef] [PubMed]

41. Theorell, H.; Holman, R.T.; Akeson, A. A note on the preparation of crystalline soy bean lipoxidase. Arch. Biochem. 1947, 14, 250-252. [PubMed]

42. Rose, D.J.; Ogden, L.V.; Dunn, M.L.; Pike, O.A. Enhanced Lipid Stability in Whole Wheat Flour by Lipase Inactivation and Antioxidant Retention. Cereal Chem. 2008, 85, 218-223. [CrossRef]

43. Aibara, S.; Ismail, I.A.; Yamashita, H.; Ohta, H.; Sekiyama, F.; Morita, Y. Changes in rice bran lipids and free amino acids during storage. Agric. Biol. Chem. 1986, 50, 665-673. [CrossRef]

44. Obadi, M.; Zhu, K.X.; Peng, W.; Noman, A.; Mohammed, K.; Zhou, H.M. Characterization of oil extracted from whole grain flour treated with ozone gas. J. Cereal Sci. 2018, 79, 527-533. [CrossRef]

45. Schaich, K.M.; Shahidi, F.; Zhong, Y.; Eskin, N.A.M. Lipid Oxidation. In Biochemistry of Foods, 3rd ed.; Eskin, N.A.M., Ed.; Elsevier: Amsterdam, The Netherlands, 2013; pp. 419-478.

46. Lampi, A.M.; Damerau, A.; Li, J.; Moisio, T.; Partanen, R.; Forssell, P.; Piironen, V. Changes in lipids and volatile compounds of oat flours and extrudates during processing and storage. J. Cereal Sci. 2015, 62, 102-109. [CrossRef]

47. Shadyro, O.I.; Sosnovskaya, A.A.; Edimecheva, I.P. Flaxseed oil stabilization using natural and synthetic antioxidants: Flaxseed oil stabilization using antioxidants. Eur. J. Lipid Sci. Tech. 2017, 119, 1700079. [CrossRef]

48. Aguiar, C.M.; Sampaio, S.C.; Santos, K.A.; Silva, E.A.; Piana, P.; Richart, A.; Reis, R.R. Total fatty acid content, antioxidant composition, antioxidant activity, and content of oil from crambe seeds cultivated with phosphorus. Eur. J. Lipid Sci. Tech. 2017, 119, 1700043. [CrossRef]

49. Kamal-Eldin, A.; Andersson, R. A multivariate study of the correlation between tocopherol content and fatty acid composition in vegetable oils. J. Am. Oil Chem. Soc. 1997, 74, 375-380. [CrossRef]

50. Kamal-Eldin, A.; Appelqvist, L.A. The chemistry and antioxidant properties of tocopherols and tocotrienols. Lipids 1996, 31, 671-701. [CrossRef]

51. Choe, E.; Min, D.B. Mechanisms and factors for edible oil oxidation. Compr. Rev. Food Sci. Food Saf. 2006, 5, 169-186. [CrossRef]

52. Kim, M.J.; Kwak, H.S.; Lee, M.J.; Kim, S.S. Quality predictive models for whole flour of immature wheat during storage and consumer acceptance on its baked product. LWT-Food Sci. Technol. 2017, 83, 42-49. [CrossRef]

53. Panseri, S.; Soncin, S.; Chiesa, L.M.; Biondi, P.A. A headspace solid-phase microextraction gas-chromatographic massspectrometric method (HS-SPME-GC/MS) to quantify hexanal in butter during storage as marker of lipid oxidation. Food Chem. 2011, 127, 886-889. [CrossRef] [PubMed]

54. Gao, C.; Li, Y.; Pan, Q.F.; Fan, M.C.; Wang, L.; Qian, H.F. Analysis of the key aroma volatile compounds in rice bran during storage and processing via HS-SPME GC/MS. J. Cereal Sci. 2021, 99, 103178. [CrossRef] 
55. Ho, C.T.; Chen, Q. Lipids in food flavors: An overview. ACS Symp. Ser. 1994, 558, 2-14.

56. Heimann, W.; Dresen, P.; Klaiber, V. Formation and decomposition of linoleic acid hydroperoxides in cereals quantitative determination of the reaction products. Z. Lebensm. Unters. Forsch. 1973, 153, 1-5. [CrossRef] 